\title{
System efficiency of PVT-collector driven heat pumps
}

\author{
Franz Hengel ${ }^{1}$, Christian Heschl ${ }^{1,2, *}$, Franz Inschlag ${ }^{2}$, and Peter Klanatsky ${ }^{2}$ \\ ${ }^{1}$ Forschung Burgenland GmbH, 7000 Eisenstadt Campus 1, Austria \\ ${ }^{2}$ University of Applied Sciences Burgenland, 7000 Eisenstadt Campus 1, Austria
}

\begin{abstract}
Standard heat pump (HP) systems with horizontal ground heat exchangers (HGHE) are commonly designed based on arbitrary knowledge gained over time and the use of the rule of thumb. Where an undersizing of the HGHE occurs, the HP efficiencies are lowered. Undersizing could result as a consequence of underestimating the soils thermal conductivity. Therefore, this paper considers the combined photovoltaic and solar thermal (PVT) collectors as an extension to standard HP heating systems with a HGHE in single-family houses with the possibility of improving the COP of the HP at a later stage and effortlessly. With the implemented hydronic scheme, the PVT-collector is also used to regenerate the soil around the ground to increase the temperature level of the heat source resulting in improved performance. However, the efficiency potential of the PV-Cells due to active cooling of the modules is analyzed. The results show an increase of the seasonal performance factor (SPF) of $4.1 \%$ and higher electric energy output of $4.4 \%$ due to active cooling of the PV-Cells while energy consumption of the regeneration pump is covered.
\end{abstract}

\section{Introduction}

The nascent technologies in the area of heat pumps (HP) heating systems for domestic hot water (DHW) generation and space heating $(\mathrm{SH})$ are becoming more common and are on track in replacing the conventional heating systems such as oil or gas boilers and direct electrical heating [1]. In addition, HPs ability to also offer cooling as an integrated application for buildings makes it a more versatile and viable option [2]. This fact is reflected in the market share involving the sale of HPs in Europe [3] as well as in Austria [4].

However, to efficiently run a HP system, the design phase of the horizontal ground heat exchanger (HGHE) for ground source heat humps (GSHP) is to be considered as an integral and important aspect. In many cases there is limited or no information about the properties of the soil, hence the HGHE could be undersized and the Coefficient of Performance (COP) decreased. Modifications of the installed HGHE could afterwards lead to very high costs and inconvenience to the user, where the garden becomes a construction site once again.

Therefore, this paper considers a system modification to improve the COP of an existing HP heating system by adding a PVT-collector and identifies parameters with high influences

\footnotetext{
*Corresponding author: christian.heschl@fh-burgenland.at
} 
concerning to the efficiency of the system. The electrical benefits of cooling PV modules is also compared to a standard PV system without cooling.

\section{Boundary conditions and modelling}

This section discusses in detail the boundary conditions, e.g. climate, building model, DHW demand and the soil, followed by the system modelling of the HP heating system, its components with/without PVT-collector as well as the control strategies.

\subsection{Climate, building model, DHW and ground}

For simulation analysis the used climate parameters of a typical mean year at the location Graz is chosen, whereby the used climate data were established with the software Meteonorm 7 between the time period of 1961 and 1990 according to [5]. Table 1 shows the detailed information about the climate in relation to position, temperatures $\left(\vartheta_{d, e}\right.$ as design ambient temperature and $\vartheta_{m, e}$ as yearly averaged temperature) and the solar irradiation for south direction and a slope of the PVT-collector of $45^{\circ}\left(I_{t o t, 45 S}\right)$. The calculated heating degree day (HDD) with a constant room temperature of $22^{\circ} \mathrm{C}$ and an upper bound of the ambient temperature of $12^{\circ} \mathrm{C}$ results in $3850 \mathrm{~K} . \mathrm{d} / \mathrm{a}$. On the other hand, the total precipitation $n_{\text {tot,pre }}$ - which affects the humidity of the soil - is assumed with $819 \mathrm{~mm}$ according to [6].

Table 1. Position, temperatures and solar irradiation at location Graz.

\begin{tabular}{|c|c|c|c|c|c|c|c|c|}
\hline Location & $\begin{array}{c}\text { Lat. } \\
\text { in }\end{array}$ & $\begin{array}{c}\text { Long. } \\
\text { in }{ }^{\circ}\end{array}$ & $\begin{array}{c}\text { Elevation } \\
\text { in } \boldsymbol{m}\end{array}$ & $\begin{array}{c}\boldsymbol{\vartheta}_{\boldsymbol{d}, \boldsymbol{e}} \\
\text { in }{ }^{\circ} \mathbf{C}\end{array}$ & $\begin{array}{c}\boldsymbol{\vartheta}_{\boldsymbol{m}, \boldsymbol{e}} \\
\text { in }{ }^{\circ} \mathbf{C}\end{array}$ & $\begin{array}{c}\boldsymbol{I}_{\text {tot,45s }} \\
\text { in } \frac{\boldsymbol{k} \boldsymbol{h}}{\boldsymbol{m}^{\mathbf{2} \cdot \boldsymbol{a}}}\end{array}$ & $\begin{array}{c}\boldsymbol{H D D} \\
\frac{\boldsymbol{K} \boldsymbol{d}}{\boldsymbol{a}}\end{array}$ & $\begin{array}{c}\boldsymbol{n}_{\text {tot,pre }} \\
\text { in } \boldsymbol{m \boldsymbol { m }}\end{array}$ \\
\hline $\mathrm{Graz}$ & $47.07 \mathrm{~N}$ & $15.44 \mathrm{E}$ & 363 & -12 & 8.36 & 1260 & 3850 & 819 \\
\hline
\end{tabular}

The building model within the simulation is designed as single-family house (SFH) with a heating load file which was established with the simulation software TRNSYS [7] beforehand. It considers four thermal zones and uses a floor heating system (FHS) with supply and return temperature $\left(\vartheta_{s, n o m} / \vartheta_{R t, n o m}\right)$ of $35^{\circ} \mathrm{C} / 28^{\circ} \mathrm{C}$. The design heat load $\dot{Q}_{H L}$ and specific heating energy demand (HED) of the SFH with a design room temperature of $22^{\circ} \mathrm{C}$ results in $3.57 \mathrm{~kW}$ and $40 \mathrm{kWh} /\left(\mathrm{m}^{2} . \mathrm{a}\right)$, respectively. The heating area of the building $A_{\text {heat,netto }}$ is $117 \mathrm{~m}^{2}$. Table 2 summarizes the basic information of the building at location Graz.

Table 2. Overview of basic building information with FHS.

\begin{tabular}{|c|c|c|c|c|c|c|}
\hline BUI & $\begin{array}{l}\boldsymbol{\vartheta}_{S, \text { nom }} \\
\text { in }^{\circ} \mathrm{C}\end{array}$ & $\begin{array}{c}\vartheta_{R t, n o m} \\
\text { in }{ }^{\circ} \mathrm{C}\end{array}$ & $\begin{array}{c}\dot{Q}_{H L} \\
\text { in } k W\end{array}$ & $\begin{array}{c}H E D \\
\text { in } \frac{k W h}{m^{2} \cdot a}\end{array}$ & $\begin{array}{c}\boldsymbol{\vartheta}_{R} \\
\text { in }{ }^{\circ} \mathbf{C}\end{array}$ & $\begin{array}{c}A_{\text {heat,netto }} \\
\quad \text { in } m^{2}\end{array}$ \\
\hline SFH & 35 & 28 & 3.57 & 40 & 22 & 117 \\
\hline
\end{tabular}

For the DHW demand, a daily periodical profile according to [8] with a fresh-water module is assumed, i.e. the daily energy demand does not vary over the year. With four persons and an intermediate DHW demand a specific tapping energy demand of $2.44 \mathrm{kWh} /($ pers $\cdot$ day) was calculated (with a temperature difference between warm and cold water $\Delta T_{D H W}$ of $35 \mathrm{~K}$ ). Therefore, a yearly DHW demand $Q_{D H W}$, dem of $3564 \mathrm{kWh} / \mathrm{a}$ was determined. Simplification was assumed for the return temperature from the fresh-water 


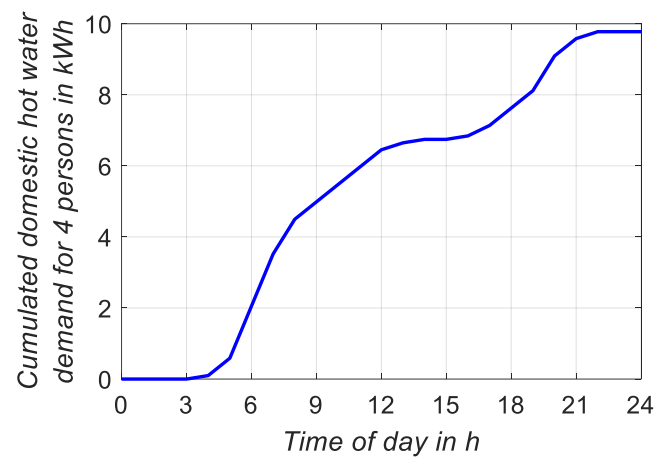

Fig. 1. Cumulated tapping energy demand for four persons over one day

module $\left(\vartheta_{R t, D H W}\right)$ with $19^{\circ} \mathrm{C}$. Table 3 shows an overview of the basic DHW information, while Fig. 1 shows the cumulated daily tapping profile for four persons.

Another boundary condition is the soil for the HGHE. As in literature discussed [9] HGHE are mainly installed in loamy to sandy soils in Austria. Concerning the simulation with a 1D consideration of the soil - and the location Graz a homogeneous soil material which combined both materials is assumed ("loamy sand"). Table 4 summarizes the basic parameters of the ground and its environment for the simulation, whereby the ground water level $z_{G W L}$ is set to $5.25 \mathrm{~m}$.

Table 3. Overview of basic DHW information.

\begin{tabular}{|c|c|c|c|c|c|}
\hline BUI & $\begin{array}{l}\text { No. of } \\
\text { person }\end{array}$ & $\begin{array}{c}Q_{D H W, \text { dem }} \\
\quad \text { in } \frac{k W h}{a}\end{array}$ & $\begin{array}{l}\Delta T_{D H W} \\
\quad \text { in } K\end{array}$ & $\begin{array}{c}V_{D H W} @ \Delta T_{D H W} \\
\text { in } \frac{m^{3}}{a}\end{array}$ & $\begin{array}{c}\vartheta_{R t, D H W} \\
\text { in }^{\circ} \mathrm{C}\end{array}$ \\
\hline SFH & 4 & 3564 & 35 & 87.6 & 19 \\
\hline
\end{tabular}

The depth of the calculation area is $20 \mathrm{~m}$, and the temperature as boundary condition at the bottom of the computational domain $\vartheta_{B C \text {,bot }}$ is set to constantly $10^{\circ} \mathrm{C}$. The surface of the ground is assumed as a lawn with an absorption factor for short-wave radiation $\left(\alpha_{S W \text {,lawn }}\right)$ of 0.75 and long-wave emissivity $\left(\epsilon_{L W, l a w n}\right)$ of 0.98 . It is also assumed that no trees are planted so that fully direct solar irradiation could hit the lawn $\left(f_{\text {sol,direct }}=1\right)$. The cloudiness factor $f_{\text {cloud }}$ is set to an average value of 0.25 according to [10] and the share of precipitation that infiltrates to the ground $f_{\text {pre }}$ is assumed as 0.5 , whereby the other $50 \%$ are considered as surface water and/or evaporation.

Table 4. Overview of basic ground information.

\begin{tabular}{|c|c|c|c|c|c|c|c|}
\hline Material & $\begin{array}{c}\boldsymbol{z}_{G W L} \\
\text { in } \mathbf{~ m}\end{array}$ & $\begin{array}{c}\boldsymbol{\vartheta}_{\boldsymbol{B C}, \text { bot }} \\
\text { in }{ }^{\circ} \mathbf{C}\end{array}$ & $\boldsymbol{\alpha}_{\boldsymbol{S W}, \text { lawn }}$ & $\boldsymbol{f}_{\text {sol,direct }}$ & $\boldsymbol{\epsilon}_{\boldsymbol{L W}, \text { top,lawn }}$ & $\boldsymbol{f}_{\text {pre }}$ & $\boldsymbol{f}_{\text {cloud }}$ \\
\hline „loamy sand“ & 5.25 & 10 & 0.75 & 1 & 0.98 & 0.5 & 0.25 \\
\hline
\end{tabular}

\subsection{Hydronic system - baseline}

The reference system (baseline) without PVT-collector consists of a GSHP with HGHE on the source side and a thermal energy storage (TES) on the sink side and is chosen based on real-built hydronic systems (Fig. 2). The HP is designed according to [9] with a heating capacity of $6.23 \mathrm{~kW}$ for brine inlet temperature of -5 and sink outlet temperature of $35^{\circ} \mathrm{C}$ 
(B-5W35) with a COP of 3.6. As a performance map of a real compressor was taken, the HP is slightly oversized since the next bigger size of the compressor was chosen. To consider the unsteady heat transfer in the soil with the implemented HGHE, an unsteady 1D-model was developed (by using the finite-volume-method to discretise the energy transport equation), and validated with measurements [11]. For the humidity in the soil, an average value over time was calculated for each cell and applied to the corresponding height as constant value.

On the sink side, the HP provides heat to the top or middle of the TES depending on the control strategy described below, but always obtains heat from the bottom of the TES. On the sink side of the TES heat can be extracted from the top to supply the fresh-water module (FWM) to prepare DHW and from the middle to provide heat for FHS. The modelling of the system was carried out in TRNSYS 17 [7], whereby Table 5 shows the description of the most important models, references and parameters.

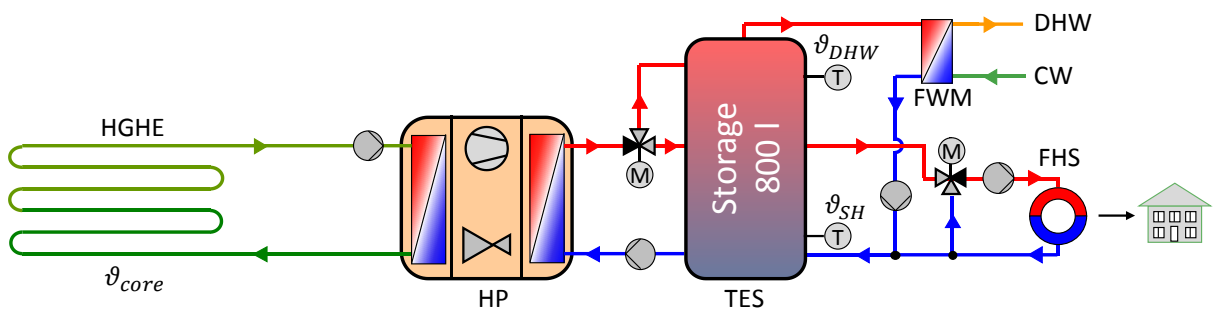

Fig. 2. Simplified hydronic scheme of the baseline with HP, TES and HGHE as main parts without any safety devices.

For the electric energy consumption, the HP calculates the amount inside the model, and for the circulation pumps high efficiency pumps are assumed with electric power of $15 \mathrm{~W}$ on the sink side, and max. $220 \mathrm{~W}$ on the source side depending on the mass flow rate. The energy consumption of all controllers is assumed at $8 \mathrm{~W}$. The nominal mass flow rates are calculated at nominal conditions (B-5W35) with $\Delta T$ of $3 \mathrm{~K}$ for the source and $\Delta T$ of $5 \mathrm{~K}$ for the sink side of the HP. The mass flow rates for DHW and SH are determined based on the load files.

Table 5. Overview simulation components, references and parameters for reference system.

\begin{tabular}{|c|c|c|c|}
\hline Modell & $\begin{array}{c}\text { TRNSYS } \\
\text { Type - } \\
\text { number }\end{array}$ & Reference & Parameter/Description \\
\hline TES & T534 & [12] & $\begin{array}{c}\text { Puffer storage; Volume: } 0.8 \mathrm{~m}^{3}, \text { Height: } 2 \mathrm{~m}, \\
\text { Medium : water; DHW with FWM } \\
\text { WP } \rightarrow \text { TES for DHW : } \\
\text { relative inlet position (RIP): } 1.0 \\
\text { relative outlet position (ROP): } 0.0 \\
\text { WP } \rightarrow \text { TES for SH: RIP: 0.67; ROP: } 0.0 \\
\text { TES } \rightarrow \text { SH (BUI): RIP: } 0.0 \text {, ROP: } 0.67 \\
\text { TES } \rightarrow \text { DHW FWM: RIP: 0.0, ROP: } 1.0 \\
\text { Relative position of temperature sensors: } \\
\text { Temperature DHW }\left(\vartheta_{D H W}\right): 0.89 \text {; Temperature SH } \\
\left(\vartheta_{S H}\right): 0.22\end{array}$ \\
\hline GSHP & T927 & {$[13]$} & $\begin{array}{l}\text { GSHP with scroll compressor (no speed drive) and } \\
\text { monovalent operation mode: } \\
\text { Heating capacity : @B-5W35: } 6.23 \mathrm{~kW} \text {, COP: } 3.6 \\
\text { Heating capacity : @B0W35: } 7.25 \mathrm{~kW} \text {, COP: } 4.2\end{array}$ \\
\hline HGHE & $\mathrm{T} 3513$ & {$[11]$} & $\begin{array}{c}\text { HGHE with ice formation: } \\
\text { Area: } 240 \mathrm{~m}^{2} \text {; pipe distance: } 0.7 \mathrm{~m} \text {, installation depth } \\
1.3 \mathrm{~m} ; \\
\text { Brine with } 35 \% \text { propylene-glycol } \\
\end{array}$ \\
\hline
\end{tabular}


The HP switches on if either the temperature at the sensor $\vartheta_{D H W}$ or $\vartheta_{S H}$ in the TES drops below a defined set point for DHW and SH, respectively. Priority is always given to DHW preparation. The HP stops if the temperature at the corresponding positions reaches an upper level. Following set points are chosen to maintain a temperature level for DHW above $45^{\circ} \mathrm{C}$ at tapping, and $35^{\circ} \mathrm{C}$ at the inlet of the FHS:

- $49^{\circ} \mathrm{C}>\vartheta_{D H W}$

- $52^{\circ} \mathrm{C}<\vartheta_{D H W}$

- $38^{\circ} \mathrm{C}>\vartheta_{S H}$

- $41^{\circ} \mathrm{C}<\vartheta_{S H}$

\author{
HP switches ON (DHW-Mode) \\ HP switches OFF (DHW-Mode) \\ HP switches ON (SH-Mode) \\ HP switches OFF (SH-Mode)
}

\subsection{Hydronic system - PVT}

A PVT-collector with validated convective heat transfer coefficient [11] is added to the baseline to improve system efficiency for existing heating systems (cf. Fig. 3). Table 6 shows the most important parameters for the simulation, e.g. size, azimuth, slope, efficiencies of the PVT-collector. The new hydronic system on the source side of the HP uses a 3-way-valve at the outlet of the evaporator that splits the mass flow rate to the HGHE or to the PVT-collector based on the control strategy. Using the latter strategy, the PVT-collector can be used to increase the temperature at the inlet of the evaporator by exploiting solar energy, or on the other hand, the PVT-collector provides energy for regenerating the soil. The latter one also shows a positive effect of increasing the efficiency of the PV modules due to active cooling with low temperatures coming from the ground. In this paper, a direct charging of the TES with the PVT-collector is not analysed, since the efficiencies of the PV modules would decrease because of the high flow temperatures. However, for the regeneration, a specific mass flow rate of $50 \mathrm{~kg} /\left(\mathrm{m}^{2} . \mathrm{h}\right)$ is assumed to keep the temperature difference low across the PVT-collector that results in a pressure drop of about 1.1 bar. For the circulation pump the same was chosen as for the source side of the baseline.

The control strategy of the PVT-collector is categorized in: ground regenerating and increasing brine inlet temperature to the evaporator. Both control strategies depend on the temperature difference of the average PVT-collector temperature $\bar{\vartheta}_{P V T}$ and the core temperature of the HGHE $\vartheta_{\text {core }}$, which is determined at the same depth as the HGHE is buried, i.e. $1.3 \mathrm{~m}$. Following temperature differences and control strategy are defined:

- $\bar{\vartheta}_{P V T}>\vartheta_{\text {core }}+6 \mathrm{~K}$

PVT-collector is activated

- $\bar{\vartheta}_{P V T}<\vartheta_{\text {core }}+1 \mathrm{~K}$

PVT-collector is deactivated

On the other hand, the mass flow rate through the PVT-collector depends on the solar irradiation, whereby a 4-step sequence control is applied. Another proportional controller ensures temperature differences between outlet and inlet of the PVT-collector of max. $5 \mathrm{~K}$ and min. $1 \mathrm{~K}$, respectively. This strategy is obtained for both regeneration - HP is off - and increasing the brine inlet temperature during HP operation. 
Table 6. Type number, references and parameters for PVT-collector.

\begin{tabular}{|c|c|c|c|}
\hline Modell & $\begin{array}{c}\text { TRNSYS } \\
\text { Type }- \\
\text { number }\end{array}$ & Reference & Parameter / Description \\
\hline $\begin{array}{c}\text { PVT- } \\
\text { collector }\end{array}$ & T560 & {$[14]$} & $\begin{array}{c}\text { Unglazed PVT-collector, without insulation; } \\
\text { Aperature area: } 20 \mathrm{~m}^{2} ; \text { slope }: 45^{\circ} ; \text { azimuth: } 0^{\circ} \\
\text { (south); } \eta_{P V}: 13 \% \text { at STC; } \dot{m}_{s p, r e g}: 50 \mathrm{~kg} /\left(\mathrm{m}^{2} . h\right)\end{array}$ \\
\hline
\end{tabular}

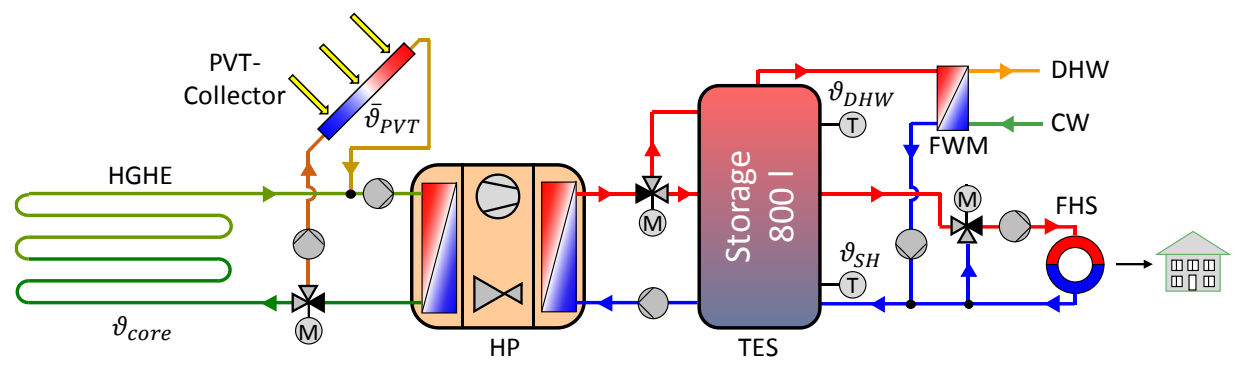

Fig. 3. Simplified hydronic scheme of the PVT-system with HP, TES, HGHE and PVT-collector as main parts without any safety devices.

\section{Results and discussion}

To assess the system two key figures are defined: the seasonal performance factor of the system $S P F_{s y s}$ (Equ. 1), and the electric energy consumption of the system $W_{e l, s y s}$ (Eq. 2).

$$
\begin{gathered}
S P F_{s y s}=\frac{\int_{0}^{8760}\left(\dot{Q}_{S H}+\dot{Q}_{D H W}\right) \cdot d t}{\int_{0}^{8760}\left(P_{e l, s y s}+P_{e l, S H, p e n}+P_{e l, D H W, p e n}\right) \cdot d t} \\
W_{e l, s y s}=\int_{0}^{8760} P_{e l, s y s} \cdot d t=\int_{0}^{8760}\left(P_{e l, H P}+P_{e l, P u}+P_{e l, c t r}\right) \cdot d t
\end{gathered}
$$

The $S P F_{s y s}$ considers the heating energy for DHW $\dot{Q}_{D H W}$ and SH $\dot{Q}_{S H}$ and set it in relation to the efforts to run the system $W_{e l, s y s}$. Equ. (1) considers also the thermal comfort for DHW $\left(\vartheta_{T E S, D H W, \text { out }}>45^{\circ} \mathrm{C}\right)$ and $\mathrm{SH}\left(\vartheta_{T E S, S H, \text { out }}>35^{\circ} \mathrm{C}\right)$ by implementing "penalties", $P_{\text {el,SH,pen }}$ $\& P_{e l, D H W, p e n}$, according to [15] with corrections from [16]. $W_{e l, s y s}$ in Eq. (2) includes the energy consumptions of HP, all circulation pumps - exception of the pump for regeneration - and the control units, also without the controller for regeneration.

Table 7. Assessment of the PVT system compared to the baseline.

\begin{tabular}{|c|c|}
\hline Key figure & Improvement in \% \\
\hline$\Delta S P F_{s y s}$ & 4.08 \\
\hline$\Delta W_{e l, S Y S}$ & 3.92 \\
\hline$\Delta W_{e l, P V}$ & 4.42 \\
\hline
\end{tabular}


For all simulations, a total duration of 10 years was simulated, whereby the last year was taken for the assessments of the system. Within this duration a quasi-stationary state occurs with deviations $<0.1 \%$ for the key figures compared to higher simulation duration. The electric energy benefit for the PVT due to active cooling is compared to the same PV modules without cooling. Table 7 shows the improvements of the key figures for the PVT-system compared to the baseline and represents the surplus of the electric energy from the PVT-system. The $S P F_{s y s}$ can be improved by about $4.1 \%$, while the electric energy consumption of the system can be reduced by about $3.9 \%$. Also, the electric energy from the PVT-collector could be increased by $4.4 \%$ compared to a standard PV system, although the efforts to run the circulation pump for regeneration of the soil has already been covered. The covering of the electric energy during regeneration is assumed to be possible because of the simultaneity (solar gains).

The improvements of the system efficiency come mainly from the active regeneration of the soil and hence increase of the temperature. Fig. 4 shows the core temperature $\vartheta_{\text {core }}$ in the same depth of the HGHE and the specific heat extraction rate over a year for both baseline (left) and PVT-system (right). Due to higher $\vartheta_{\text {core }}$ of the PVT-system the HP operates with higher COP's and hence affects the seasonal performance factor in a positive way. As it is observed, the core temperature can be increased by $4 \mathrm{~K}$ in the summer and stays about $1.5 \mathrm{~K}$ above at the end of January, where most of the heat is extracted from the ground and only less regeneration from the surface of the ground takes place.

Furthermore, the investigation shows only minor effects to increase the inlet temperature at the evaporator due to PVT system during HP operation. This can be justified that in winter the solar gains for the PVT-collector are low but heating demand is at highest, and in summer the provided energy is only for DHW. However, the share of it counts about $10 \%$ from the total energy providing on the source side for the HP. Another point is that DHW preparation is mainly done in the morning where solar gains are zero or very little. This leads also to only minor effects on the inlet temperature of the evaporator.

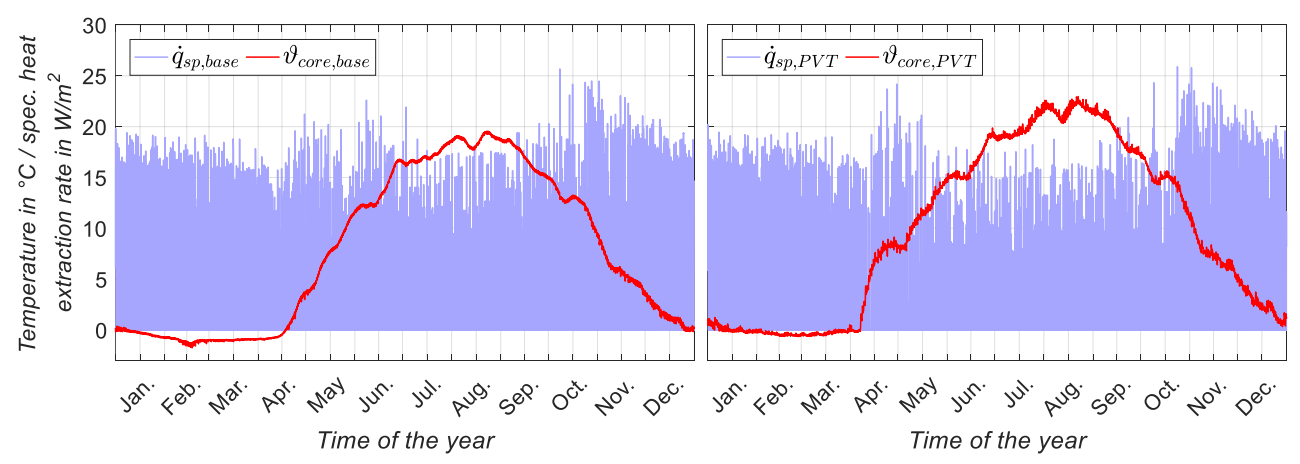

Fig. 4. Core temperature $\vartheta_{\text {core }}$ and specific heat extraction rate $\dot{q}_{s p}$ of the baseline (left) and PVT-system (right).

\section{Summary}

In this paper, an implementation of a PVT-collector to an existing heat pump (HP) heating system is compared to a standard HP heating system for a low energy single-family house consisting of four persons at location Graz. The PVT-collector provides thermal energy to increase the inlet temperature of the evaporator and to raise the ground temperature level to obtain higher COP and hence higher seasonal performance factors. To use the PVT system, 
a proper control strategy was defined for the investigations. On the sink side of the HP, a thermal energy storage tank was used to provide energy for domestic hot water and space heating, whereby for the latter the heat is provided to a floor heating system.

The considered system was modeled in TRNSYS 17, whereby a simulation duration of 10 years was chosen to get quasi-stationary conditions of the soil. The results show improvements of the seasonal performance factor $S P F_{s y s}$ of about $4.1 \%$ and electrical energy savings of about $3.9 \%$. The main parameter to increase the system's performance was the active regeneration of the ground, and hence the increased core temperature which is in the same depth of the horizontal ground heat exchanger. The simulations showed temperature differences between PVT-system and baseline of about $4 \mathrm{~K}$ in the summer, and $1.5 \mathrm{~K}$ in the coldest phase of the year. The influence of the PVT-collector to increase the inlet temperature of the evaporator showed only minor effects due to the low simultaneity of solar irradiation and running the heat pump. For all simulations, the electric energy demand for the circulation pump during regeneration has been already covered from the PVT-collector as simultaneity occurs. Also, the electric energy gains of the PVT-collector could be increased by $4.2 \%$ compared to a PV system without active cooling. The energy demand for regeneration was already subtracted from this result.

However, heat pump systems with added PVT-collectors leads to increase of both, system efficiency of the heat pump system mainly due to regeneration of the soil, and increasing of the electric energy gains from cooled PV-Cells. On the other hand, high investment costs occur for the installation of the PVT-system, which diminishes the profitability with these assumptions. Further work could focus on a detailed analysis of the cost of such systems and where the break-even-point will be attained.

The research leading to these results has received funding from the Klima- und Energiefond's programme "ENERGY MISSION AUSTRIA" under grant agreement No. 843809 - acronym "CoolPV" and from the European Union's Horizon 2020 research and innovation programme under grant agreement No. 818342 - acronym "PVadapt".

\section{References}

1. K. J. Chua, S. K. Chou, W. M. Yang, Applied Energy 87, 3611-3624 (2010)

2. M. Hartl, P. Biermayr, A. Schneeberger, P. Schofmann, Bericht aus Energie- und Umweltforschung 8, (2016)

3. T. Nowak, Heat pump market statistics report 2013 (European Heat Pump Summit, 15-16, Nuremberg, Germany, 2013)

4. Austrian Energy Agency, Heizkostenvergleich, Neubau (2017) [Online] Available at: https://www.energyagency.at/faktenservice/heizkosten/neubau.html

5. M. William, U.Ken, User's Manual for TMY2s. Golden, Colorado, US: NREL (1995)

6. ZAMG, Klimadaten von Österreich 1971 - 2000 (2016) Online: http://www.zamg.ac. at/fix/klima/oe71-00/klima2000/klimadaten_oesterreich_1971_frame1.htm

7. S. A. Klein, TRNSYS 17: A Transient System Simulation Program, Solar Energy Laboratory, University of Wisconsin, Madison, USA (2012)

8. H. Feurich, Sanitärtechnik - Grundlagen der Sanitärtechnik (7. Ed., Hrsg. Mönchengladbach, Germany: Druckhaus B. Kühlen KG, 1995)

9. H. Huber, Wärmepumpen, Erdkollektoren, Garten- und Wohnqualität (Wien, Land Niederösterreich, Verein für Konsumenteninformation, Leistungsgemeinschaft Wärmepumpe Austria, 2006) 
10. PIC, Potsdam Institute for Climate Impact Research (2016) Online: https://www.pikpotsdam.de/services/infothek/telegraphenberg-d/suering-haus/sakularstation

11. K. Kreuter, K. Paar, R. Zweiler, H. Focke, R. Hofstätter, F. Hengel, C. Heschl, P. Klanatsky, S. Langerwisch, F. Inschlag, S. Amon, H. Poier, M. Schubert, Cool PVSystemkombination von PV-Hybridmodulen und Wärmepumpen mit Erdreichkollektoren zur Effizienzsteigerung beider Anlagen (Final report of Klima- und Energiefond, 2016)

12. TESSLibs17, TESSLibs 17 - Component Libraries for the TRNSYS Simulation Environment - Volume 11 - Storage Tank Library Mathematical Reference, Wisconsin, USA: Thermal Energy System Specialists, LLC of Madison (2012)

13. TESSLibs17, TESSLibs 17 - Component Libraries for the TRNSYS Simulation Environment - Volume 4 - GHP Library Mathematical Reference, Wisconsin, USA: Thermal Energy System Specialists, LLC of Madison (2012)

14. TESSLibs17, TESSLibs 17 - Component Libraries for the TRNSYS Simulation Environment - Volume 03 - Electrical Library Mathematical Reference, Wisconsin, USA: Thermal Energy System Specialists, LLC of Madison (2012)

15. W. Streicher, M. Haller, Structure of the Reference Building of Task 26, A Report of IEA SHC-Task 26 Subtask C: Solar Combisystems, s.l.: IEA SHC (2003)

16. R. Heimrath, M. Haller, Project Report A2 of Subtask A: The Reference Heating System, the Template Solar System - A Report of IEA SHC Task 32: Advanced Storage Concepts for Solar and Low Energy Buildings, s.1.: IEA SHC (2007) 